\title{
Diversification of ceramic craft for tourism souvenirs: local culture as art creation and production idea
}

\author{
Ponimin ${ }^{\mathrm{a}, 1, *}$ \\ ${ }^{a}$ Department of Arts and Design, Faculty of Letters, Universitas Negeri Malang, Indonesia \\ ponimin.fs@um.ac.id* \\ * corresponding author
}

ARTICLE INFO

Article history

Received 2021-03-02

Revised 2021-05-21

Accepted 2021-05-28

Keywords:

Diversification

Design

Ceramic

Craft

Souvenir

\section{ABSTRACT}

The tourism industry and craft products are two sectors that are long developed, complementing and strengthening each other. However, not many people consider ceramic craft product design with local culture basis. The research aims to show how local culture can be used as the source for ceramic craft product design ideas. Through design innovation and production techniques, we can increase varieties of ceramic craft product design. To make it come true, it needs a creative method as its solution. Creative method application includes: (1) Developing ceramic craft design for souvenir, based on local culture; (2) ceramic craft visual exploration for souvenir sourced from the local culture with Kerapan Sapi Madura (Cow Racing) as creation idea; (3) Ceramic craft production technique for souvenir; (4) Improvement and analysis of ceramic craft product innovation for a souvenir. (5) Analysis of creation result. Creation results can be seen from two design sets of ceramic craft products based on local culture with the "Kerapan Sapi Madura (Cow Racing)" theme as a product design idea.

This is an open-access article under the CC-BY-SA license.

\section{Introduction}

Craft art and tourism are two inseparable aspects regarding creative industry sector development. Their relations have given a significant contribution to economic and cultural development in Indonesia and also various. Studies show that there are so many tourism souvenirs in various tourism regions in various countries that their design idea came from the local culture. Design ideas can be derived from attraction culture or artifact cultures such as art, traditional ceremonies, architecture, statues, monuments, and local icons. They can be met in tourism centers on Bali island. There are many souvenir products from wood, textile, and other miscellaneous crafts. Similar phenomena can also be found in Singapore [1]. Tourists will easily find various tourism souvenirs describing Merlion (Statue with lion head and fish body) [2]. Souvenir craft with different icon designs can also be found in Thale Noi, Phatthalung, Thailand tourism center [3]. When visiting Jaipur Rajastan, India, we can also meet souvenir product designs created from architecture around the Jaipur region or local statues. Various tourism centers around the world present souvenir craft products with local artifacts and attraction culture as creative ideas. Culture is then created into souvenir products with various styles, functions, techniques, and materials. Creation results, on the other side, also enrich local culture through various souvenir crafts. It also enriches the diversity of souvenirs consumed by tourists, so it will improve the local community economy since souvenir diversity also increases consumers' options to buy it [4][5].

The researcher's study showed that there is a lack of souvenir products developed using ceramic media in various tourism regions in Malang, East Java, and various tourism objects. Souvenir craft products are generally dominated by synthetic media, such as fiberglass, textiles, and other synthetic media. On the other side, souvenir craft design ideas with local culture themes are also not much 
developed. According to that situation analysis, this innovative art research is essential to produce a concept design and ceramic design that enrich ceramic design products for tourism. In order to focus on problem-solving, there are important problems to be formulated. (1) How to design concept formulation of souvenir ceramic product with local culture basis as creation idea. (2) How to establish design in the creative process includes exploration, design image, modeling process, and craft reproduction process for a ceramic souvenir. Regarding such problems, it needs ceramic craft development method.

\section{Method}

The creative method of ceramic craft product design development for souvenirs is designed by considering craft product design principles. To reach such creation, creative research methods are needed to be applied, including: (1) Design concept related to shape, ornament, size, related with product uniqueness; (2) design visual exploration process by creating alternative design image; (3) technique and production process exploration. Technique exploration is by processing material from Malang local clay, creating model, continued with reproduction and firing process; (4) validation and improvement to creation result, involving product design experts and tourism creative industry subjects; (5) Analysis of creation result for souvenir product and in this case, using "Kerapan Sapi (Cow Racing)" theme as creation idea for tourism souvenir. This souvenir ceramic creation is expected to have competitive value in developing the tourism sector [6], [7]. Figure 1 shows steps in developing ceramic product innovation based on local culture.

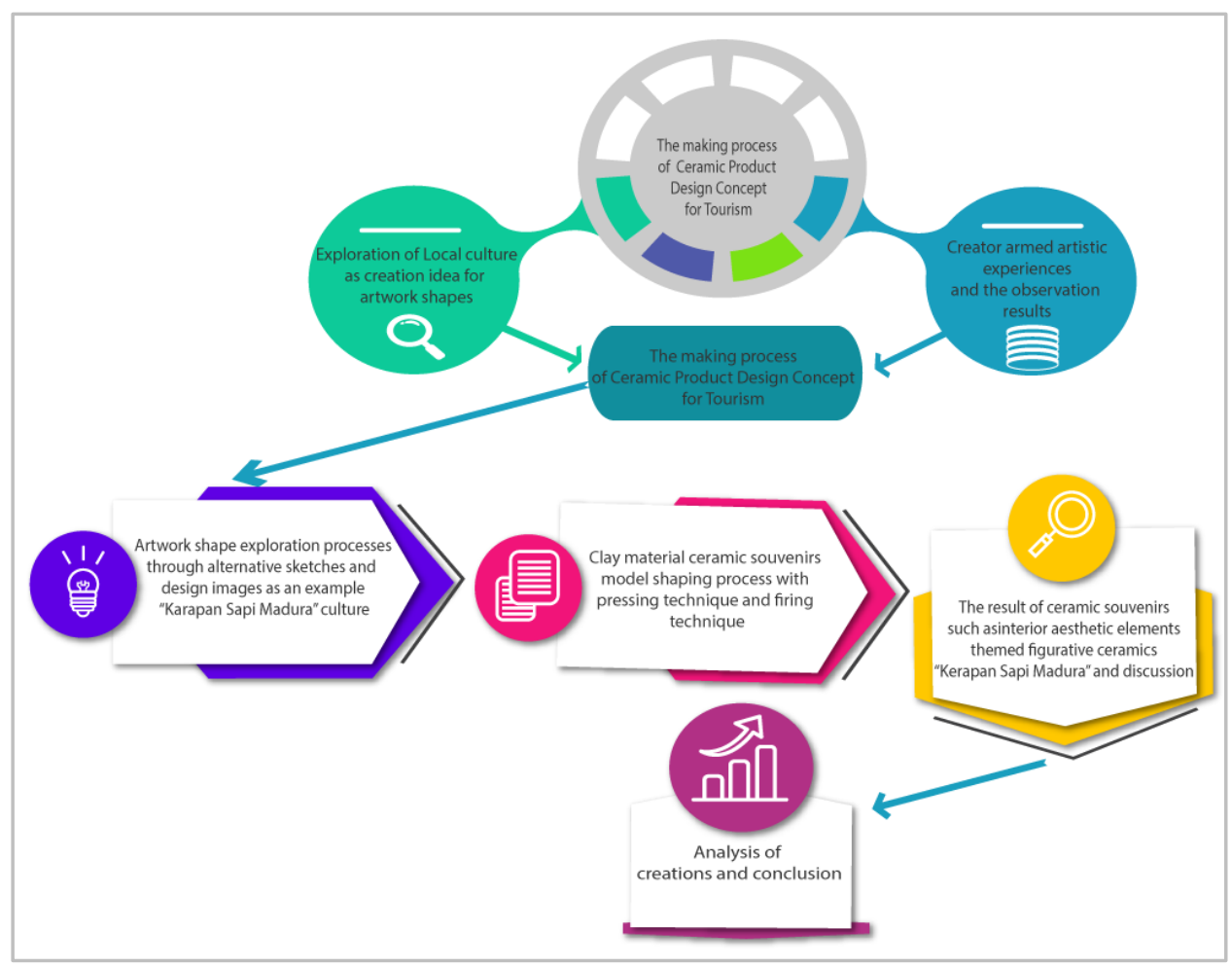

Fig. 1. The local culture-based ceramic creation process for tourism souvenir

Ceramic product design is developed with local culture as a creative idea by considering ceramic as creation media. From here, the researcher developed some product design concepts. This brought researchers to artwork shape exploration through alternative sketches and design images. After deciding on some sketches and design, the researcher created a clay material artwork model using pressing and firing techniques. After the artwork finished, the researcher did some review and discussion regarding the artwork to determine whether they are already suitable for research purposes. This artwork would then add a new perspective that local culture can be used as a source for ceramic craft product design ideas [8]. 


\section{Results and Discussion}

\subsection{Local Culture Study and Ceramic Craft Art for Tourism Souvenir}

Tourism will receive a positive effect when a tourism destination has some uniqueness. On the other side, it will leave a unique impression on people who visit the region [9]. Visitors in their origin region cannot find such uniqueness. For example, tourists from China, Netherland, Japan, and various world regions visited the Yogyakarta region because they demand new experiences and knowledge regarding nature and cultural uniqueness that they cannot find in their place. That is why business institutions or communities need to pay attention to developing their economy or culture by providing something different demanded by those tourists [10]. Various local culture spread in Indonesia is an incredible source that would never run out to dig, a process explored, then visualized to ceramic craft art product for tourism to support tourism. Unique local culture supported by nature as ceramic material and human resource as the creative subject of ceramic craft art product can strengthen craft art, which further expanded to tourism sector development. Ceramic craft product design development will be the main strength to develop the tourism industry. Spreading of ceramic craft centers that produced interior and exterior aesthetic element items in various regions needs development in ceramic product design for tourism. Technical skills owed by ceramic crafters to process local clays and shape them into ceramic artwork have become part of Indonesia's ceramic craft community's production process. So, the craft center region needs to develop its ceramic craft product for tourism by using local cultural potentials as their creative design idea. Surely this creative process needs to pay attention to aspects related to craft for tourism souvenirs [11], [12].

Tourism consumers in the tourism region commonly wanted unique products in the form of unique crafts. That is why ceramic craft products for tourism are designed by paying attention to such demand. The researcher's observation shows that there are many souvenir craft marketed in various tourism regions - for example, a souvenir from textiles, fiberglass, wood, cement, and other material. Ceramic craft products for souvenirs based on local material (ceramic) are less produced by ceramic crafters or tourism industry managers. That is why product design development based on local culture as a creative idea is worth doing. This development can enrich Indonesian culture and economic development for the community [5]. Indeed, it is important to formulate ceramic design development for souvenir principles based on product design in this development process. Design should be done by paying attention to the uniqueness aspect, practicality, symbols, affordable price for tourists, effectivity and efficiency of production, and unique factor that reflected local culture. Tourists who visit specific regions will demand souvenir products with such principles. Packed souvenir products should pay attention to convenience, ergonomics, and good competing value in marketing aspects or consumer range [11].

Indonesia's various cultures, but not all, easily derived into ceramic design ideas for a souvenir. However, it needs study and appreciation of such culture. Idea source should be deepened by considering the uniqueness aspect from created value and culture. In addition, when creating souvenir products, it needs further consideration to apply the visual complexity of such culture. Other aspects are also considered reproduction aspects, where products are embodied into mass souvenir products [12]. The abundance of clay material available and technical skills owed by crafters also good assets to support development. Souvenir ceramic design needs clay as the primary material. The clay used is an environmentally friendly material. So, when the material is no longer used, it can be recycled by nature. This souvenir ceramic product will be good to be developed in ceramic crafters environment so that this ceramic development would not absorb high production costs. Souvenir ceramic development refers to that principle that indeed has huge potential to increase economy and culture in the community, which is ceramic craft culture. Indeed in its development, we need to pay attention to the things mentioned above. So that the achievement can be fulfilled. The development process is started by formulating concept and design exploration process, also prototype product and reproduction creation [7].

\subsection{Design concept formulation}

It has developed a souvenir ceramic design concept that comes from value and shapes uniqueness from local Indonesian culture as a creative idea. The culture can be attraction or artifact culture. Design concept formulation can be achieved by paying attention to craft design uniqueness principles. Design uniqueness aspect can describe destination local culture. One ceramic craft is designed by describing 
the local culture, which becomes a destination for tourists. So when a consumer buys the product, it can be a special memory for tourists [13].

On the other hand, a souvenir shape design with specific local culture ideas can be an intermediary for communication and promotion regarding that tourism region. People will be curious to see the souvenir displayed in households or tourists' favorite spots [14]. For example, in developing ceramic craft product design for souvenirs, one selected theme for this item is "Kerapan Sapi Madura (Cow Racing)" attraction as a basic idea. This "Kerapan Sapi (Cow Racing)" attraction is a local culture from Madura. The attraction is held in traditional harvest ceremonies. Usually, it is held in the open field. "Kerapan Sapi (Cow Racing)" attraction can be described as cow racing with a jockey who controls the cow. This Jockey ride on 'Panangkok' - a tool to drive and control cows located behind the animal. There are also traditional attributes, consist of carving ornaments on cows' necks. A hook was attached between two cows so that the jockey would be able to ride on it.

Jockey uses some whip to spur the cows. There is various decoration attached on the cows as well. In this ceramic product design development, visual aesthetic aspects are also considered. Visual aspects which become a cultural icon, when created as souvenir product, will look attractive. Creation from the "Kerapan Sapi (Cow Racing)" image is developed into a design that will attract tourists' interest. There is a deformation element from the "Kerapan Sapi (Cow Racing)" main shape and also visual elements in a new form but did not leave a unique impression from the product. Shape creation considers technical aspects, production, and packaging technique after the product ready [11].

Ceramic craft, as a mass-produced product, still pays attention to technical simplicity in the production process phase. Production process considered simplicity and cost range to process material and also shaping technique. On the other side, ornament detail creation in visual looks can be done. Another aspect that needs attention is product packaging. It can make product distribution easier as a souvenir for consumers. There is also text which helped to describe local culture, which brought as creation idea. It will strengthen consumer memory of places they visit [7].

\subsection{Design Exploration and Ceramic Craft Production Technique for Souvenir}

Shape and technique exploration is a visual creative activity part of embodying design concept to artwork. The shape exploration process is an early phase in visual exploration done by the researcher. It was done by creating alternative design images for artwork. Various shapes are explored by drawing artwork design in various alternatives. Here, the researcher draws the raw image of "Kerapan Sapi Madura (Cow Racing)" in various alternative sketches. "Kerapan Sapi Madura (Cow Racing)" attraction culture is re-created through sketches by displaying visual impressions that the consumer can catch and understand. When embodied into artwork, a visual impression representing the idea source should be kept [14].

The sketch image creation process as part of exploration is done by creating various alternative sketches. It has done so that can be selected an image to be selected as a prototype design. Selected sketch improved into design picture described in Figure 2a and Figure 2b. In the designing process, it is important to emphasize aesthetics and practicality. It involves visual aspects in the creation process, includes original culture form that appears to be deformed. This creation result should be impressive. However, a visual impression regarding the culture should be attached to the product. In this research, the "Kerapan Sapi Madura (Cow Racing)" attraction. There is a visual display of cows attached in ornament panangkok and a ride by the jockey.

On the other side, while creating souvenir designs, the visual aspect is not the only one paid attention to. We also have to focus on function and production techniques. Design development also needs to consider aspects related to function and production technique. Shape aspect, related with visual elements such as line, field, volume, surface texture, color composition. To reach it, an alternative design image creation process is made by considering various visual possibilities. Shape alternatives should be prepared to be selected, fixed, and embodied in the product prototype [15]. Design image (Figure 2a) Front side image and (Figure 2.b) side image of ceramic design for tourism souvenir with "Kerapan Sapi Madura" theme. 


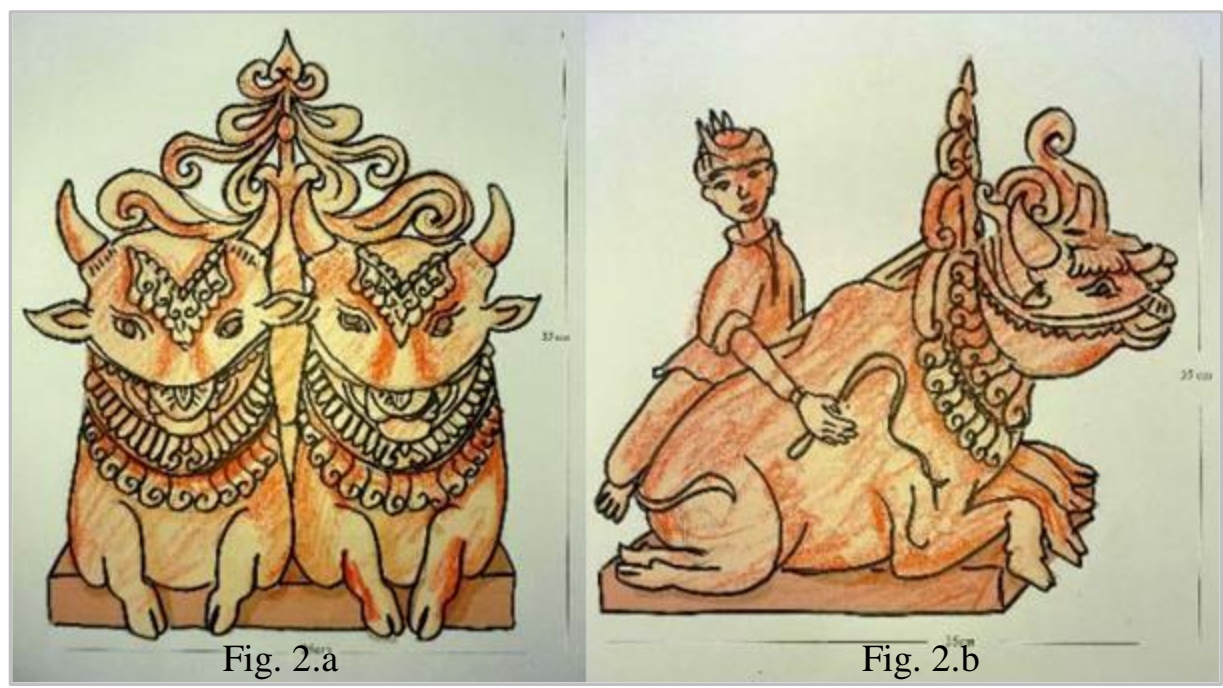

Fig. 2. Ceramic design for tourism souvenir with "Kerapan Sapi Madura"

Function aspect consideration in a souvenir is also important. Sometimes, souvenir products from ceramic also functioned practically and can be put as the display (accessory). In practical function, its functional aspects should still be related to aesthetics. Function and aesthetic should be considered well to have a shape to be selected by potential consumers [14]. Technique exploration aimed to collect possibilities regarding preferred techniques. To reach a qualified product, technique exploration is also important. That is why the technique exploration process should be done by still considering clays as the main ingredient for artwork. This clay is prepared from the Southern Malang region. Technique exploration includes material processing. Material processing is done by mixing local clay, quartz sand, and kaolin, comparing 50\% clay, $20 \%$ quartz, and 30\% Kaolin. Mixture materials are then processed in a plastic way and homogenous using a plastic clay processor. Plastic material processing and press print reproduction technique are applied by traditional crafters in the Malang region, as shown in Figure 3.

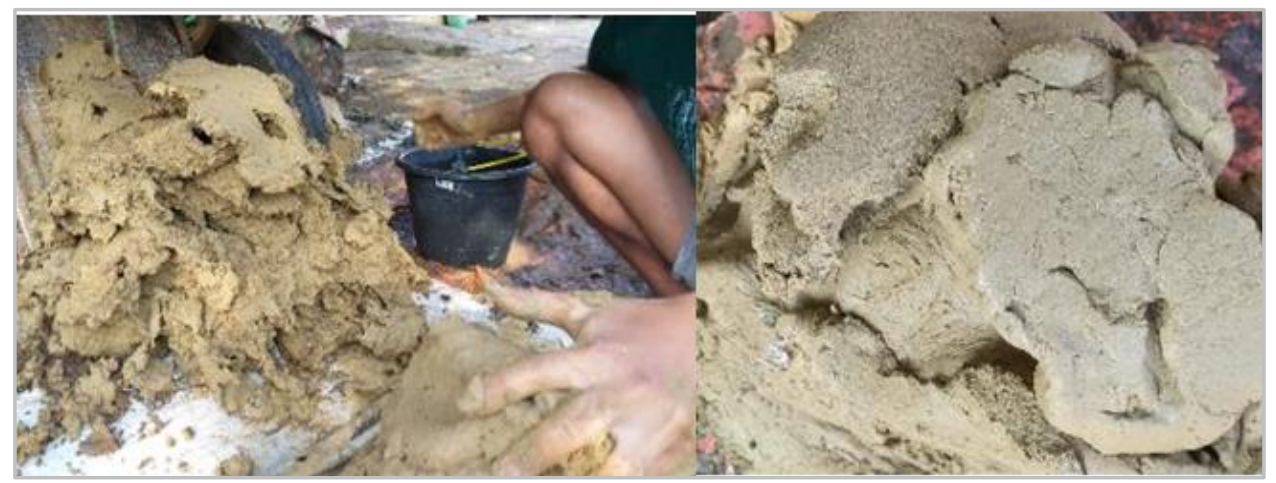

Fig. 3. Malang local clay processing, preparation for ceramic reproduction using press print technique

Production technique implementation can be adjusted with crafters' experience in each ceramic center. The artwork production process then proceeds using the manual press print shaping technique [1]. The artwork production process begins by creating a product prototype referred to as design. The product prototype is made from ceramic with three-dimensional models using plastic clays. Model creation referred to design image from "Kerapan Sapi Madura (Cow Racing)" shape. This shape design is made by using the pinching technique (direct hand press). The shaping process is started by pressing plastic clays until raw artwork is shaped. This raw artwork was treated to create detailed anatomy as a visual character determined. When artwork shape is perfectly created, the next phase creates ornament in the surface and other shapes designed as previously drawn. When shaping detail and ornament are finished, the process continued with souvenir reproduction [4]. The reproduction 
process is done by the press print shaping technique prepared from gypsum print. The reproduction process by press print from gypsum printing tool is started by preparing printing tool from gypsum which already printed based on model. From this gypsum printing tool, the artwork was then reproduced by plastic clay. The modeling phase for the reproduction process uses the pinching technique that can be seen in Figure 4.

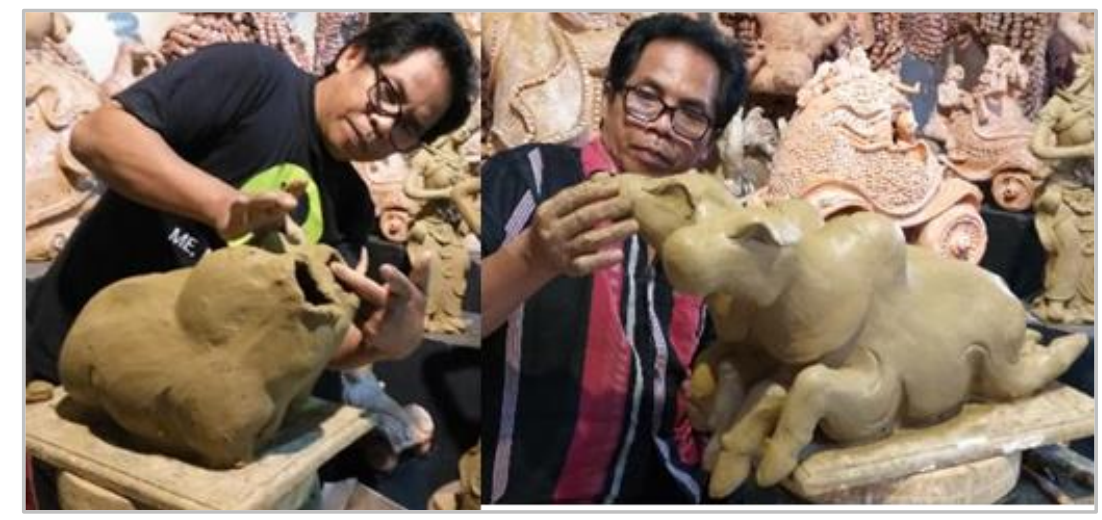

Fig. 4. "Kerapan Sapi” model shaping for souvenir, made from Malang local clay material

Reproducing process is done by flattening and inserting clays into the gypsum printing tool slowly. In this press print technique reproduction, not all elements from artwork can be done altogether [16]. There are specific details from the shape which cannot be printed directly using one printing model. There are some bulges from the inhibiting model in the press print process, which releases some complex and bulging shapes. The shape is commonly harder to release from gypsum. That is why the reproduction process with the press print technique needs to pay attention to aspects related to bulges and details of shape anatomy and ornament complexity in artwork reproduction [17]. This reproduction activity is tested to find the perfect shape and ready to proceed in the firing process. Before the firing process, the artwork product is dried first. The drying process is done in a closed room with good hot air circulation to dry the artwork. This drying process is suitable for local clay material souvenir ceramic products before dried under the sun. The direct sunlight drying process can be done when souvenir ceramic product no longer has water content [18]. In the drying process in a room under the roof, there will be shrinkage in ceramic slowly. Next, when the water content in the ceramic body has dried, the artwork is then arranged in a firing stove. Arrangement in the stove is started from the lower part of the stove to the upper room.

The arranging process in the firing room should be done by paying attention to the hot air circulation aspect in the firing process. It is done so that heat from the firing room will reach its optimum temperature equally [19]. When the souvenir product arrangement is finished, the stove door will be closed, and the firing process is started. The early firing phase is done by initiating minimum fire. It is done so that the heat would not be too strong. The low-temperature firing process is done in about 4 hours so that the heat spread over the firing room. If the warming up process has reached 4 hours, the following process is maturation. This process is held for about 1,5 hours. Ceramic artwork maturation is done by increasing fire from four fire sources in the source to reach $900^{\circ} \mathrm{C}$ temperature [18]. When the firing room has reached the intended temperature, the fire will be shut gradually. After that, the firing room will experience a cooling process for 12 hours. After all, a process is done, artworks can be removed from the firing stove [20]. Ceramic product design diversification is done by taking "Kerapan Sapi Madura (Cow Racing)" as an example. The product functions as an interior aesthetic element expressed visually in the form of a deformation of a couple of racing cows controlled by a man with Madura's traditional outfit on their back. In the cows' heads, neck, and back, there is some spiral-shaped clay. The diversification product result is shown in Figure 5. 


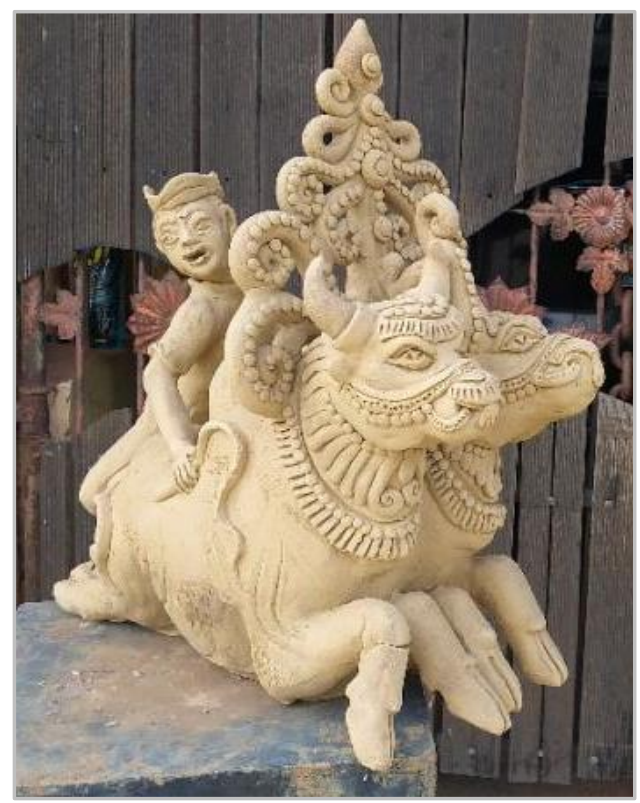

Fig. 5. Design development result for souvenir product with "Kerapan Sapi Madura (Cow Racing)" theme

\subsection{Aesthetic Creation Products}

Experience in an impressive tourism journey is everyone's desire. The experience will be more memorable when something from a tourism destination can be brought to remember the journey. Souvenir craft products offer to fulfill this kind of demand [10]. It can also have some effect on the object visited. The tourists will talk about souvenir craft products they collect from tourism objects to their friends and family. Tourism experiences with souvenir craft products from tourist spots are inseparable. That is why it is important to develop souvenir craft products for a tourist region. This unique product should have specific uniqueness. It will make the tourism object have a positive image of visitors' memory after visiting the tourism object [21], [22]. Tourism administrators, community, and other creative subjects are expected to understand this problem as essential to develop souvenir ceramic craft as part of tourism region development. Understanding this issue is an asset to develop their product. In turn, they will receive benefits economically and culturally. With various local cultures in diverse regions, Indonesia lacks ceramic activists to develop souvenir ceramic designs with fresh creative ideas [13]. These developed souvenirs, in addition to unique items with economic function, also have cultural meaning. Viewed from economic function, the product plays an important role in increasing tourism business people and craft producers. From a cultural aspect point of view, souvenir craft products designed from local culture also play an important role in improving the cultural image. It because the product will be brought to tourists' hometowns and displayed in their homes. So those products are a representation of the destination tourism region [23].

Through this research, there is a creative activity referred to produce souvenir ceramic craft products. These products support the tourism sector. Souvenir ceramic craft and tourism are two unified elements that need each other and complement each other to develop the creative industry. The tourism region has done much development in souvenir ceramic craft product design referred to local culture, whether attraction or artifact culture [24]. Observation also shows that not many souvenir ceramic product creation ideas are derived from the local culture. The development is still dominated by synthetical media or less environmentally friendly material. Ceramic as the main material for souvenir craft products is selected since it is made from local environmentally friendly material. Development result is expected to compete in cultural and economic. This design considers tourists' needs. Tourists in making their journey generally want something unique, representing objects they visited. This memorable thing is a souvenir which they cannot get from other regions. They commonly want unique souvenir craft products. The uniqueness can be viewed from the shape (design) also material (working technique) [25], [26]. Research to develop this product is done to answer the chance to be implemented to the community, ceramic crafters, or tourism business people. Souvenir product design development in Indonesia, especially in Malang as a tourism region, shouldn't focus on synthetical material-based products. Developing souvenir ceramic craft in our Archipelago, especially in Malang Area products as a memento for tourists, should be artistic, ergonomic, convenient, and 
affordable for the consumer (fulfilling economic aspect). By fulfilling this aspect, this development result will compete in the tourism market [23]. The development process consists of several phases: idea source collection and design concept formulation, design and technique exploration, and product embodiment. Souvenir ceramic craft product design development took local culture example, "Kerapan Sapi Madura (Cow Racing)" as an interior aesthetic element. This local culture product is created by still referring to its design principles [27].

Design shape exploration is done by creating various alternatives for artwork in image media. This process explores varieties of shapes that can be embodied into the ceramic product, as stated by N. R. Kalita. A creator will search for possible shapes to be applied in their artwork, which is done through the creative activity of playing shapes. In creating this shape, design principle consideration become the basis for creation [24]. It is related to composition consideration, uniqueness, contrast, harmony between visual elements, and art language from a product. On the other side, their art language as a creative product includes line elements, shape, field, texture shapes from souvenir craft products [1] [24], [28]. To realize souvenir ceramic design, the press print shaping technique is used. Material to turn the design into the product is a local clay from Malang processed by a plastic system. Souvenir ceramic craft production process by local clay and press print creation technique is worth applying in the souvenir craft production process. The material is abundant and easy to process using a simple technique. In addition, artwork created using the press print technique can be applied for artwork production in a massive amount. This souvenir ceramic craft product requirement will be met when applying production techniques with economical cost. Besides, we can still achieve artwork with unique shapes and practical functions [29].

\section{Conclusion}

Indonesia is a country with the various local culture which can be processed as a creative idea source for souvenir ceramic product design. Local culture processing can be used to support the tourism industry and the culture itself. Craft design development for tourism is also part of the activity to improve the community's economy, local culture, also tourism itself. Ceramic craft art design development plays an important role. In addition, as a souvenir when visiting a specific region, it also improves the region's image. Cultural diversity will never be dry when we use it as a source to create ceramic artwork for a souvenir. There is a local product development concept through this creative research through the "Kerapan Sapi Madura (Cow Racing)" attraction theme. The creative process starts from product design concept formulation, design exploration, and technique exploration until embodied as artwork. Design and technique exploration are product shape exploration referred to as design concept, while technique exploration is preparing local clay material and artwork shaping until it becomes ceramic artwork for a souvenir. This creative research is expected to contribute to crafters' society around Malang. Local culture as a design idea is selected because of its visual shape uniqueness. Shape elements in creation will be attached to consumers' minds as memorable goods. Indeed its creation process should consider shape uniqueness, function, and practicability aspects so that the ceramic craft development process for souvenirs in its finishing process will be able to give a contribution to creative industry development.

\section{References}

[1] P., "Themed Figurative Ceramic Artistic Creation from Local Culture Inspiration," KnE Soc. Sci., vol. 3, no. 10, p. 280, Mar. 2019, doi: 10.18502/kss.v3i10.3909.

[2] P. Hayward, "Merlionicity: The twenty first century elaboration of a Singaporean symbol," J. Mar. Isl. Cult., vol. 1, no. 2, pp. 113-125, Dec. 2012, doi: 10.1016/j.imic.2012.11.008.

[3] Weerawan Marangkun and Auntika Thipjumnong, "Souvenir Product Purchasing as a Travel Motivation in the Shopping Area of Thale Noi, Phatthalung, Thailand," J. Tour. Hosp. Manag., vol. 6, no. 2, Apr. 2018, doi: 10.17265/2328-2169/2018.04.002.

[4] L. F. Amaral, J. P. R. G. de Carvalho, B. M. da Silva, G. C. G. Delaqua, S. N. Monteiro, and C. M. F. Vieira, "Development of ceramic paver with ornamental rock waste," J. Mater. Res. Technol., vol. 8, no. 1, pp. 599-608, Jan. 2019, doi: 10.1016/j.jmrt.2018.05.009.

[5] X. Greffe, "From culture to creativity and the creative economy: A new agenda for cultural economics," City, Cult. Soc., vol. 7, no. 2, pp. 71-74, Jun. 2016, doi: 10.1016/j.ccs.2015.12.008. 
[6] P. Leavy, Method meets art: Arts-based research practice. Guilford Publications, 2020. Available at: Google Book.

[7] G. Ponimin, "Expressing the Robustness of Love in Ceramic Art: A Creative Approach Study," ANASTASIS. Res. Mediev. Cult. Art, vol. VII, no. 2, pp. 285-306, 2020. Available at: anastasis-review.

[8] L. J. Chutia and M. K. Sarma, "Commercialization of Traditional Crafts of South and South East Asia: A Conceptual Model based on Review of Literature," IIM Kozhikode Soc. Manag. Rev., vol. 5, no. 2, pp. 107-119, Jul. 2016, doi: 10.1177/2277975215624728.

[9] D. Joo, H. Cho, and K. M. Woosnam, "Exploring tourists' perceptions of tourism impacts," Tour. Manag. Perspect., vol. 31, pp. 231-235, Jul. 2019, doi: 10.1016/j.tmp.2019.05.008.

[10] H. Chen and I. Rahman, "Cultural tourism: An analysis of engagement, cultural contact, memorable tourism experience and destination loyalty," Tour. Manag. Perspect., vol. 26, pp. 153-163, Apr. 2018, doi: 10.1016/j.tmp.2017.10.006.

[11] T. Young Choi, "Producing the Past: The Native Arts, Mass Tourism, and Souvenirs in Victorian India," Lit Lit. Interpret. Theory, vol. 27, no. 1, pp. 50-70, Jan. 2016, doi: 10.1080/10436928.2015.1131360.

[12] D. An and N. Youn, "The inspirational power of arts on creativity," J. Bus. Res., vol. 85, pp. 467-475, Apr. 2018, doi: 10.1016/j.jbusres.2017.10.025.

[13] J. Cave and D. Buda, "Souvenirs in Dark Tourism: Emotions and Symbols," in The Palgrave Handbook of Dark Tourism Studies, London: Palgrave Macmillan UK, 2018, pp. 707-726. doi: 10.1057/978-1-13747566-4_29

[14] C. Wulf, "The mimetic creation of the Imaginary," Aisthesis. Prat. linguaggi e saperi dell'estetico, vol. 12, no. 1, pp. 5-14, 2019. Available at: Google Scholar.

[15] J. Forsey, "Aesthetic Experience, Aesthetic Value," Estet. Eur. J. Aesthet., vol. 54, no. 2, p. 175, Sep. 2017, doi: 10.33134/eeja.162.

[16] P. Ponimin, "Diversifikasi desain produk sentra keramik dinoyo bersumber ide budaya lokal Malang," Bhs. dan Seni J. Bahasa, Sastra, Seni, dan Pengajarannya, vol. 46, no. 1, pp. 111-123, Mar. 2018, doi: 10.17977/um015v46i12018p111.

[17] I. Campione, C. Fragassa, and A. Martini, "Kinematics optimization of the polishing process of largesized ceramic slabs," Int. J. Adv. Manuf. Technol., vol. 103, no. 1-4, pp. 1325-1336, Jul. 2019, doi: 10.1007/s00170-019-03623-3.

[18] F. Pardo, S. Meseguer, M. M. Jordán, T. Sanfeliu, and I. González, "Firing transformations of Chilean clays for the manufacture of ceramic tile bodies," Appl. Clay Sci., vol. 51, no. 1-2, pp. 147-150, Jan. 2011, doi: 10.1016/j.clay.2010.11.022.

[19] A. Mezquita, J. Boix, E. Monfort, and G. Mallol, "Energy saving in ceramic tile kilns: Cooling gas heat recovery," Appl. Therm. Eng., vol. 65, no. 1-2, pp. 102-110, Apr. 2014, doi: 10.1016/j.applthermaleng.2014.01.002.

[20] Ponimin, Hariyanto, B. Bin Isa, and Suharmanto, "Development of graft earthenware ceramic firing stove design from the usage of wasted gas fire and heat from tunnel stove in stoneware ceramic firing process," 2020, p. 030021, doi: 10.1063/5.0000893.

[21] H. Jiang, "Research on the Calcination Craft and Artistic Styles of Chinese Jun Porcelain," in Proceedings of the 6th International Conference on Arts, Design and Contemporary Education (ICADCE 2020), 2021, doi: 10.2991/assehr.k.210106.127.

[22] D. Hume, Tourism Art and Souvenirs. Routledge, 2013. doi: 10.4324/9780203771488

[23] P. Cooke, "Green design aesthetics: Ten principles," City, Cult. Soc., vol. 3, no. 4, pp. 293-302, Dec. 2012, doi: 10.1016/j.ccs.2012.11.001.

[24] N. R. Kalita, "The Art of Re-Interpreting Self: Self Imagery in the Works of Indian Artists," Int. J. Vis. Perform. Arts, vol. 1, no. 2, pp. 69-79, Nov. 2019, doi: 10.31763/viperarts.v1i2.52.

[25] M. Banks, "Craft labour and creative industries," Int. J. Cult. Policy, vol. 16, no. 3, pp. 305-321, Aug. 2010, doi: 10.1080/10286630903055885. 
[26] N. Afatara, "The Creation of Contemporary Artwork," in Proceedings of the Third International Conference of Arts, Language and Culture (ICALC 2018), 2019, doi: 10.2991/icalc-18.2019.9.

[27] M. Brück, "Aesthetic principles, the arts, and the interpretation of culture," PsyCh J., vol. 10, no. 2, pp. 200-209, Apr. 2021, doi: 10.1002/pchj.406.

[28] L. Puppe, H. Jossberger, and H. Gruber, "Creation Processes of Professional Artists and Art Students in Sculpting," Empir. Stud. Arts, vol. 39, no. 2, pp. 171-193, Jul. 2021, doi: 10.1177/0276237420942716.

[29] F. Angelini and M. Castellani, "Cultural and economic value: a critical review," J. Cult. Econ., vol. 43, no. 2, pp. 173-188, Jun. 2019, doi: 10.1007/s10824-018-9334-4. 